\title{
COMMENTARY
}

\section{Trade and public health}

\author{
Ashley Schram PhD, Ronald Labonté PhD
}

Cite as: CMAJ 2017 July 4;189:E879-80. doi: 10.1503/cmaj.170089

See related article at www.cmaj.ca/lookup/doi/10.1503/cmaj.161152

A $s$ the number of new negotiations of regional trade and investment agreements has grown in recent years, evidence is mounting about their implications for population health. ${ }^{1,2} \mathrm{~A}$ linked CMAJ article by Barlow and colleagues is the latest to examine trade and investment policy as a plausible causal driver of diet-related health outcomes through high-sugar, high-fat and high-sodium food products. ${ }^{3}$ The authors found that even the minor reductions in tariff rates brought in by the North American Free Trade Agreement (NAFTA) on products such as high-fructose corn syrup, a common additive to sugar-sweetened beverages and other highly processed food products, were strongly associated with the increased supply of such commodities into Canada. Recent actions of US President Donald Trump, such as promising to renegotiate NAFTA or abandoning the TransPacific Partnership and the Transatlantic Trade and Investment Partnership - which many in public health advocated against ${ }^{1}-$ may signal to some that the health risks of trade and investment liberalization within North America will be diminished. On the contrary, the public health community should seize the opportunities presented by new and reopened negotiations, and the growing body of empirical work to which Barlow and colleagues' article contributes, to advocate for health and health inequities as fundamental considerations in these agreements.

Although President Trump has said little about what he would want out of a renegotiated NAFTA, apart from halting the migration of US factories and jobs to Mexico, a Canadian ambassador to the United States has suggested that, if NAFTA is reopened, Canada will insist on resolving the dispute over Canadian exports of softwood lumber to the US - previously valued at $\$ 5$ billion in illegitimate duties charged over a four-year period on Canadian softwood lumber by the US. ${ }^{4}$ Although Canadian trade negotiators may be eager to recapture lost revenue on softwood lumber, they should be considering another number $-\$ 7$ billion - the annual estimated cost of obesity to the Canadian economy, ${ }^{5}$ which is driven in no small part by increasing availability of relatively cheap ultraprocessed food products (e.g., those containing high quantities of refined sugars). As the article by Barlow and colleagues shows, such consumption rose after trade and investment liberalization that occurred under NAFTA.

Increased availability of unhealthy food products is only one of the many pathways through which trade and investment liber-

\section{KEY POINTS}

- Evidence is accumulating regarding the negative implications of international trade and investment agreements for public health, which frequently promote increased foreign direct investment and international supply chain integration.

- Potential shifts in trade and investment agreement negotiations as a result of changes in policy following the election of US President Donald Trump may create new opportunities for public health to ensure health equity and environmental sustainability on any new or reopened trade and investment agenda.

- Public health professionals should engage with Canadian trade negotiators on the role that trade and investment policy plays in driving the current obesity epidemic, in Canada as well as globally, to ensure evidence-informed policy-making in the area of trade and health.

alization has the capacity to negatively affect health. Trade and investment provisions can promote the spread of other unhealthy commodities, such as tobacco and alcohol, partly through the protections offered to foreign investors in such products. ${ }^{6,7}$ Through enhanced intellectual property rights, trade and investment agreements can increase the delay of market entry of more affordable generic medicines, alongside increasing opportunities for the private provision of health insurance and health services that may limit affordable access to necessary medical care. ${ }^{8,9}$ In addition, trade and investment negotiations often privilege the role of the private sector in advising on development of the eventual treaties, such as the participation of over 600 corporate advisors to the US team negotiating the Trans-Pacific Partnership. ${ }^{10}$ This practice, although unsurprising because trade and investment agreements in essence are commercial agreements, nonetheless provides the private sector considerable influence over internationally binding terms that condition and constrain future domestic health-promoting policy space. ${ }^{11}$ Finally, enforcement mechanisms such as investor-state dispute settlement, which allow private investors to pursue international arbitration against states when new regulatory measures are perceived to damage investor profits, provide another channel through which the private sector can influence decisions by policy-makers by threatening costly arbitration. ${ }^{12}$ 
Although US-led regional agreements may be set to dissolve, many countries (including the US) will continue to pursue treaties bilaterally, ${ }^{13}$ and regional trade and investment agreements are likely to continue to flourish with efforts to create a "TransPacific Partnership minus one" (plus China and South Korea) already underway. Consequently, the public health concerns over trade and investment regimes are no less urgent now than before President Trump's change in US policy direction.

The uncertainty surrounding future trade negotiations, together with the economic impacts and societal value of trade and investment agreements being increasingly questioned in the mainstream media, provides public health with a new opportunity to influence the conversation. Public health should take advantage of the newly shifted terrain to make the case that any trade or investment policy that prizes economic growth over reducing health inequities and enhancing ecological sustainability is bad policy. Health equity and environmental sustainability - in line with the new Sustainable Development Goals must be central to any reopened trade agenda. Moving forward, researchers in this area must communicate a clear direction to policy-makers on revising these deals to enhance protection for population health and health regulatory measures. Concurrently, health policy-makers must increase multisectoral efforts to communicate these recommended directions and advocate their necessity to trade and investment negotiating bodies in the government. Finally, enhanced roles for academic, civil society and nongovernmental organizations in this process are required to ensure that these deals represent a broader array of interests. This extends to the ongoing accumulation of evidence of the health affects (both positive and negative) of our present trade and investment agreements.

The methods used by Barlow and colleagues provide an important and uniquely rigorous approach to this type of evidence gathering, indicative of newer and more robust methodological approaches that are now being used in the pursuit of evidence-informed policy in the area of trade and health. However, in the "post-truth" and "alt-fact" era in which we currently live, where untruths are spread with ease and believed by many, developing evidence-informed policy may be challenging. Each new piece of evidence that details how trade and investment agreements affect health is vital; however, the efforts of public health advocates to help generate the public and political will to act upon it is more important.

\section{References}

1. Labonté R, Schram A, Ruckert A. The Trans-Pacific Partnership: Is it everything we feared for health? Int J Health Policy Manag 2016;5:487-96.

2. Hirono K, Haigh F, Gleeson D, et al. Negotiating healthy trade in Australia: a health Impact assessment of the proposed Trans-Pacific Partnership Agreement. Liverpool (AU): Centre for Health Equity Training Research and Evaluation; 2015.

3. Barlow P, McKee M, Basu S, et al. Impact of the North American Free Trade Agreement on high-fructose corn syrup supply in Canada: a natural experiment using synthetic control methods. CMAJ 2017;189:E881-7.

4. Hasselback $D$. The granddaddy of all Canadian-US trade disputes is about to rear its ugly head again. Financial Post [Toronto] 2014 Oct. 31. Available: http://business .financialpost.com/news/economy/the-granddaddy-of-all-canadian-u-s-trade -disputes-is-about-to-rear-its-ugly-head-again (accessed 2017 May 3).

5. Picard A. Obesity costs economy up to \$7-billion a year. The Globe and Mail [Toronto] 2011 June 20. Available: www.theglobeandmail.com/life/health-and-fitness/health/ conditions/obesity-costs-economy-up-to-7-billion-a-year/article583803 (accessed 2017 May 3).

6. Kelsey J. The implications of new generation free trade agreements for alcohol policies. Addiction 2012;107:1719-21.

7. Kelsey J. The Trans-Pacific Partnership Agreement: A gold-plated gift to the global tobacco industry? Am J Law Med 2013;39:237-64.

8. Lexchin J, Gagnon MA. CETA and pharmaceuticals: impact of the trade agreement between Europe and Canada on the costs of patented drugs. Ottawa: Canadian Centre for Policy Alternatives; 2013.

9. Fact sheet: public health care costs less, delivers more. Ottawa: Canadian Union of Public Employees; 2013. Available: http://cupe.ca/fact-sheet-public-health -care-costs-less-delivers-more (accessed 2016 Mar. 2).

10. Palmberg E. The insider list. Sojourners [Washington] 2012 June 29. Available: https://sojo.net/articles/insider-list (accessed 2015 Dec. 9).

11. Koivusalo M, Labonté R, Wibulpolpraset S, et al. Globalization and national policy space for health and a HiAP approach. In: Leppo K, Ollila E, Pẽna S, et al., editors. Health in all policies. Finland: Ministry of Social Affairs and Health; 2013.

12. Tienhaara K. Regulatory chill and the threat of arbitration: a view from political science. In: Brown C, Miles K, editors. Evolution In Investment Treaty Law and Arbitration. London (UK): Cambridge University Press; 2011.

13. Labonté R, Schram A, Ruckert R. The TPP is dead, long live the TPP? A response to recent commentaries. Int J Health Policy Manag 2017;6:1-3.

\section{Competing interests: None declared.}

Affiliations: School of Regulation and Global Governance (RegNet) (Schram), ANU College of Asia \& the Pacific, The Australian National University, Acton, ACT, Australia; School of Epidemiology (Labonté), Public Health and Preventive Medicine, University of Ottawa, Ottawa, Ont.

Contributors: Ashley Schram wrote the first draft of the article and Ronald Labonté revised it. Both of the authors revised the article critically for important intellectual content, gave final approval of the version to be published and agreed to be accountable for all aspects of the work.

This article was solicited and has not been peer reviewed.

Correspondence to: Ronald Labonté, rlabonte@uottawa.ca 